\title{
INTERCULTURAL COMMUNICATION
}

DOI https://doi.org/10.30525/978-9934-26-039-1-87

\section{КРАЇНОЗНАВЧІ ТЕКСТИ В МУЛЬТИКУЛЬТУРНИХ ГРУПАХ: СПЕЦИФІКА ВИВЧЕННЯ}

\author{
Назаревич Л. Т. \\ кандидатка філологічних наук, \\ доччентка кафедри украӥнської та іноземних мов \\ Тернопільського начіонального технічного університету \\ імені Івана Пулюя \\ м. Тернопіль, Україна \\ Денисюк Н. Р. \\ кандидатка філологічних наук, \\ доцентка кафедри украӥнської та іноземних мов \\ Тернопільського начіонального технічного університету \\ імені Івана Пулюя \\ м. Тернопіль, Україна
}

Котовська T. I.

кандидатка філологічних наук, доиентка кафедри іноземних мов

та інформаційно-комунікаційних технологій

Західноукраӥнського начіонального університету

м. Тернопіль, Україна

«Українська мова як іноземна» $є$ базовою дисципліною для інокомунікантів, які здобувають вищу освіту в Україні. Завдання викладача ретельно вибирати змістове наповнення й методичний апарат, структурувати завдання, підбирати цікавий ненав'язливий історико-культурний матеріал для читання, дотримуватися принципу послідовності та наступності.

Інтерес до української мови як іноземної зростає, і з кожним роком 3'являється все більше методологічних і наукових праць, де чільне місце посідають країнознавчі тексти. Такі матеріали сприяють зануренню інокомунікантів у культуру на вербальному та невербальному рівнях, 
крім того, вони є підгрунтям для опанування граматико-стилістичних конструкцій, засобом отримання необхідної інформації в незнайомому середовищі. В Україні лінгвокраїнознавчим аспектам приділяють увагу О. Антонів， О. Горда， Н. Малюга， Д. Мазурик， Г. Швець， М. Редьква, Н. Сарновська, О. Трумко, О. Шевченко та ін. Ганна Швець у монографії «Теорія і практика навчання української мови іноземних студентів гуманітарних спеціальностей» зауважує: «Навчальні наукові тексти про Україну, які становлять основу підручника 3 країнознавства i які використовують також у практичному курсі УМI, називають країнознавчими» [5, с. 259].

Удосконалення навичок мовлення студента, вміле використання типових кліше залежно від ситуації $€$ основною метою викладача на заняттях УМІ. Реалізація цієї мети формується на базі читацької компетентності. Етикетні формули, прислів'я, приказки, рецепти національної кухні, рекламні тексти про архітектурні чи культурні пам'ятки, аналіз карт, сучасні статті на україномовних сайтах («Ukraïner», «Мандруй Україною», «Музей Гончара», блог Ореста Зуба «Подорожуй. Навчайся. Заробляй» та ін.), відгуки про екскурсії та подорожі пробуджують інтерес до комунікації. На основі вищезазначеного варто вибудовувати роботу з усними та письмовими текстами.

На початковому рівні опанування мови не варто занурюватися в складні сторінки історичного минулого або конструювати ідеальну Україну з усіма її архетипами, однак тим, хто вивчає українську мову як іноземну на рівні В1-B2, C1-C2, треба пропонувати тексти та завдання, які б відкривали більше фактів про природу, історію, економіку, культуру, традиції України. Гуморески, новини, статті 3 преси, відеоролики про мандри Україною, кухню, побут, музику слугують доречним ілюстративним матеріалом, який ненав'язливо знайомить чужоземців з нашими реаліями. За останні роки методологічна база поповнилася доробками українських лінгвістів, зокрема «Знайомтесь! Київ» Г. Швець, «Яблуко», «Мандрівка Україною», «Ключ до України. Міста і люди» та ін. Новинкою $є$ підручник «Ключ до України. Міста i люди» [2]. Усі тексти про міста, історичні події, листи, фрагменти 3 виступів відомих людей, уривки із сучасної художньої літератури, світлини підпорядковуються ідеї транслювати правду про Україну, розвінчувати міфи, викликати інтерес до самоосвіти.

У Тернопільському національному технічному університеті імені Івана Пулюя студенти-іноземці навчаються за підручником «Українська мова для іноземців» Л. Назаревич, Н. Гавдиди [3]. Крізь призму сучасних 
i народних пісень, текстів про Т. Шевченка, I. Пулюя, С. Патона, М. Сядристого та ін., таких тем, як «Київ - столиця України», «Місто Тернопіль», «Традиції України», «Великдень» тощо українська мова позиціюється як соціокультурний феномен у системі національних цінностей України. Крім навчальних текстів, практикуємо роботу 3 піснями, адже мультикультурні групи активно реагують на українську музику, охоче працюють 3 текстами пісень на фонетичному, лексичному та граматичному рівнях. Про це грунтовніше йдеться в праці «Пісенна творчість - компонент методики навчання української мови як іноземної» [4, с. 95]. Сучасні онлайн-інструменти дають можливість геймифікувати опанування граматики, тому, виходячи із запиту на легкість навчання, пропонуємо студентам виконувати інтерактивні вправи на платформах Wizer.me (https://wizer.me/) та Learningapps (https://learningapps.org), де, крім слухання, запам'ятовування самого тексту, є змога закріплювати знання 3 морфології та синтаксису (наприклад, http://bit.ly/rizdvyani-pisni-kolyadki).

Застосування лінгвокультурологічного підходу на занятті дозволяє іноземцям зануритися в атмосферу традицій українців. Починати заняття, присвячені різдвяному циклу, пропонуємо 3 дотекстової лексики: перша зірка, Святвечір, кутя, колядники, ялинка, дідух, ясла та ін., яка супроводжується візуалізацією та коментарями, де тлумачення слугує поясненням специфічних культурних реалій та допомагає здолати труднощі лінгвокраїнознавчого характеру на дотекстовому етапі.

Необхідною $є$ робота з адаптованими й неадаптованими текстами, 3 дозовано введеними ідіомами. У згаданому підручнику [3] є чимало прикладів використання фразеологізмів, окремий розділ присвячено мовним конструкціям та зворотам щодо висловлення власної думки, прохання про пораду, висловлення компліментів, обурення, протесту, заборони, вимоги. Для того, щоби студенти розуміли, де, коли і як використовувати ту чи іншу конструкцію, пропонуємо на початку заняття працювати з базовою лексикою, зокрема 3 антонімами, синонімами, видами дієслів, емоційними та нейтральними висловлюваннями, а після цього переходити до такого типу вправ: продовжте речення, доповніть висловлювання фразеологізмами з рамки, доповніть діалоги необхідними висловлюваннями, відповідно до ситуації доберіть коректний фразеологізм. Ми звернули увагу на те, що відтворення різностильових діалогів, з використанням одних і тих же мовних кліше в різних контекстах, сприяють автоматизації мовлення. На рівні В1-В2, вважаємо вдалими завдання такого типу: змоделюйте ситуацію, де можна вжити такі конструкиії: «та от, тиждень уже голову над иџим сушу...», «чоловіче, май, врешті, свій розум!», «ти маєш Божу іскру!», 
«y нього від твоїх слів виросли крила». Така практика допомагає мультикультурним групам збагнути, як за допомогою тієї чи іншої ідіоми можна збудувати або зруйнувати комунікаційні кордони. Доречне вживання ідіом допомагає іноземцям продемонструвати знання мови на рівні носія та дає можливість зрозуміти, що є ідіоми-маркери української мови: чорноброва дівчина - це не просто дівчина з чорними бровами, а символ української вроди, прилетіла ластівочка - не стільки про приліт пташки, скільки про прихід весни, а вислів язик до Києва заведе - це не про те, що язик може ходити, а про те, що про все можна дізнатися, якщо бути допитливим, комунікабельним. Скоромовок теж не слід оминати увагою на всіх етапах опанування мови.

Варто зауважити, що є необхідність пов'язувати нову інформацію 3 уже відомим матеріалом, а незнайомі слова пояснювати, наводити приклади та порівняння, адже якщо цього не робити, то студенти приходять на заняття неготовими, власне, неготовність часто зумовлена тим, що вони мають справу з важкими для розуміння текстами. Кожна іноземна мова - окремий світ, а «ці світи не є несумісними, радикально відмінними, вони резонують між собою, але ніколи не збігаються повністю $[1$, с. 7]. Отож «окремі світи» потребують осмислення через різні канали комунікації, через різні види аудиторної та післяаудиторної роботи. Рідковживана лексика складніша для сприйняття через низьку частотність вживання, тому потребує неабиякої праці зі сторони студента i викладача. Завдання викладача - активізувати пам'ять студента за допомогою візуалізації, інтервального повторення, аналогії, вправ різного рівня складності на розвиток зв'язного мовлення (перефразовувати сполучення слів, написати речення із запропонованих слів, поставити до речень усі можливі запитання, замінити розповідні речення питальними, переказати фрагмент тексту, продовжити текст, написати есе, розповідь чи резюме до тексту та ін.). Зауважимо, що ускладнені дієприслівниковими зворотами, або надто довгі речення доцільно спрощувати, розбивати на кілька окремих частин.

Отож, робота 3 країнознавчими текстами допомагає швидше опанувати опорний лексичний мінімум, розвинути гнучкість мислення, сприяє розпізнаванню мовних явищ, їх кваліфікацію, групування та класифікацію, виявляе порушень мовних норм, допомагає розвивати навички зв'язного мовлення студентів та формувати уявлення про ментальність, манеру поведінки людей, історичну правду країни, де іноземні громадяни навчаються. Вселяє оптимізм те, що з'являється все більше матеріалів, які популяризують Україну у світі та формують лінгвокраїнознавчі знання про нашу країну. 


\section{Література:}

1. Кассен Б. Більше однієї мови / Пер. 3 фр. С. Желдак. Київ : ДУХ І ЛІТЕРА, 2016. $64 \mathrm{c}$.

2. Ключ до України : міста і люди : підручник з української мови як іноземної (Рівні В2-С1) / [Ключковська І., Горда О., Трумко О., Мартинишин Н., Темник Г., Руснак О.] - Ч. 2. - Львів : Колір ПРО, 2020. 296 с.

3. Назаревич Л. Т., Гавдида Н. І. Українська мова для іноземців. Практикум (Рівні В1-В2). Тернопіль : ФОП Паляниця В. А., 2017. 212 с.

4. Назаревич Л., Денисюк Н. Пісенна творчість - компонент методики навчання української мови як іноземної // Актуальні проблеми лінгводидактики в сучасному освітньому середовищі : матеріали Всеукраїнської науково-практичної інтернет-конференції (з міжнародною участю) / за заг. ред. Г. Дідук-Ступ’як, Т. Миколенко, М. Пігур. 2-ге вид., перероб. і доп. Тернопіль : Вектор, 2020. 258 с.

5. Швець Г. Теорія і практика навчання української мови іноземних студентів гуманітарних спеціальностей : монографія. Київ : Фенікс, 2019. $529 \mathrm{c}$.

DOI https://doi.org/10.30525/978-9934-26-039-1-88

\section{VOCATIVES IN ENGLISH AND UKRAINIAN}

\section{Sokolets I. I.}

Candidate of Pedagogical Sciences, Associate Professor, Associate Professor at the Department of Germanic and Finno-Ugric Philology named after Professor G. G. Pocheptsov

Kyiv National Linguistic University

Kyiv, Ukraine

\section{Khanykina N. V.}

Candidate of Philological Sciences,

Senior Researcher at the Scientific Research Laboratory of Education Borys Grinchenko Kyiv University

Kyiv, Ukraine

Vocatives are an important component of communication. These words and expressions are widely used in almost all languages to call «the attention of an addressee, in order to establish or maintain a relationship between this addressee and some proposition» [3, p. 267]. 